\title{
Kegiatan Tabligh di Kalangan Penyandang Disabilitas Tunarungu Wicara
}

\author{
Nizam Mahlufi ${ }^{{ }^{*}}$, Sitti Sumijaty ${ }^{1}$, Mukhlis Aliyudin ${ }^{2}$ \\ ${ }^{1}$ Jurusan Komunikasi dan Penyiaran Islam, UIN Sunan Gunung Djati, Bandung \\ *Email : mablufin@gmail.com
}

\begin{abstract}
ABSTRAK
Di Jama'ah Tabligh Al-Latifah Buah Batu terdapat penyandang disabilitas tunarungu wicara. Para mubaligh disana menggunakan cara khusus untuk menyampaikan materi tablighnya kepada penyandang disabilitas dengan menggunakan Bahasa Isyarat dengan pendekatan Komunikasi Total. Adapun tujuan penelitian ini untuk mengetahui proses tabligh terhadap penyandang tunarungu wicara, materi tabligh yang disampakan terhadap penyandang tunarungu dan metode yang dilakukan dalam penyampaian materi tabligh terhadap penyandang tunarungu wicara di Jama'ah Tabligh Al-Latifah Buah Batu. Penelitian ini menggunakan metode penelitian dekriptif dengan pendekatan kualitatif dengan mengumpulkan, menganalisis data yang menggambarkan situasi kedaan dan hasil temuan lapangan yang bersifat non-hipotesis, selanjutnya mendeskripsikan apa yang dilihat, didengar, dirasakan, dan ditanyakan. Hasil penelitian ini menunjukkan bahwa kegiatan tabligh pada proses pelakasanaanya menemukan berbagai macam hambatan, Hambatan-hambatan tersebut adalah: (a) Perbedaan Kemampuan dalam Berbahasa Isyarat, (b) Hambatan lainya. Oleh karena itu ada upaya dalam mengatasi hambatan-hambatan, guna mengoptimalkan peyampaian materi menjadi lebih baik lagi : Mempedalam Bahasa Isyarat Komunikasi Total, (b) Pendekatan Secara Psikologis
\end{abstract}

Kata kunci : Tabligh; Tunarungu Wicara; Komunikasi Total.

\section{ABSTRACT}

In Jama'ah Tabligh Al-Latifah Buah Batu there are persons with hearing impairments. The preachers there use a special method to convey their material to persons with disabilities using Sign Language using the Total Communication approach. The purpose of this study is to find out how the tabligh process of deaf people is speaking, what material is tabligh delivered to deaf people and how the method is carried out in delivering tabligh material to deaf people in Jama'ah Tabligh Al-Latifah Buah Batu. This research uses descriptive research method with a qualitative approach by collecting, analyzing data describing the situation of the situation and the results of non-hypothesis field findings, then describing what is seen, heard, felt, and asked. The results of this study indicate that tabligh activities in the implementation process find a variety of obstacles, these obstacles are: (a) Differences in Sign Language 
Ability, (b) Other obstacles. Therefore there are efforts in overcoming obstacles, in order to optimize the delivery of material to be even better: Deepening the Total Communication Sign Language, (b) Psychological Approach.

Keywords : Tabligh; Deaf speech; Total Communication.

\section{PENDAHULUAN}

Masyarakat Islam sama seperti masyarakat yang lainya, ada yang memiliki kondisi fisik normal dan ada juga yang menyandang keterbatasan fisik atau disabilitas, kondisi penyandang disabilitas memperihatinkan karena kurangnya kepedulian terhadap penyandang disabilitas tidak semuanya di perhatikan, dari segi hak hidup, pekerjaan, pendidikan, fasilitas, dan juga kurangnya perhatian dalam kehidupan beragama. Hal ini membuat kaum penyandang disabilitas merasa dimarjinalkan, sehingga tidak sedikit dari mereka yang kehilangan kepercayaan diri.

Namun dengan berkembangnya zaman, penyandang disabilitas pada saat ini mendapatkan perlakuan yang khusus dan sama rata dengan masyarakat pada umumnya, seperti dari segi keadilan dan perlindungan hukum, pendidikan, pekerjaan, kwirausahaan, kesehatan, keberagamaan, keolahragaan kebudayaan dan pariwisata, kesejahteraan sosial, hidup secara mandiri dan dilibatkan di masyarakat, berkomunikasi dan memperoleh informasi. Hal ini menjadikan mereka bebas dari tindakan diskriminasi dari masyarakat yang memiliki kehidupan yang layak atau memiliki fisik normal.

Islam adalah agama dakwah, artinya agama yang senantiasa mendorong pemeluknya untuk aktif melakukan kegiatan dakwah. Kemajuan dan kemunduran Islam sangat erat kaitannya dengan kegiatan dakwah yang dilakukan. Oleh karena itu Al Qur'an menyebutkan dengan ucapan dan perbuatan yang baik. Pertolongan Allah akan senantiasa diberikan kepada siapa saja yang patut mendapatkannya, yakni mereka-mereka yang senantiasa menegakan agama yang benar dan senantiasa menegakkan amar ma'ruf nahyi munkar. Dakwah dilakukan untuk merubah perilaku, sikap dan tabiat manusia ke arah yang lebih baik. Karena demikian pentingnya dakwah, maka Rasullulah SAW senantiasa melakukan dakwah sepanjang hidupnya untuk merubah manusia dari satu kondisi ke kondisi yang lain. Dakwah dilakukan Rasullulah SAW memperoleh kesuksesan yang luar biasa. Bukti kesuksesan tersebut adalah berubahnya kondisi masyarakat Arab dari zaman jahiliah menjadi masyarakat yang beradab dan berprilaku Islam.

Dakwah merupakan suatu kegiatan yang sudah ada sejak dulu, yaitu sejak diturunkannya tugas dan fungsi yang harus dipikul oleh manusia selama hidupnya (Enjang dkk : 2009). Kegiatan dakwah ini berfungsi untuk mengajak umat manusia kejalan Allah SWT, dan khususnya umat islam mempunyai fungsi 
sebagai pengingat atau memperdalam ke islamannya. Dakwah dapat dilakukan dengan berbagai cara, yaitu dakwah dalam bentuk irsyad, tadbir,tathwir dan tabligh. Tabligh atau ceramah adalah teknik dakwah yang banyak digunakan para ulama dalam menyampaikan ajaran-ajaran Islam kepada umat manusia. Teknik ini lebih banyak digunakan karena ceramah lebih mudah dan praktis dalam menyelenggarakannya.Pelaksanaan kegiatan tabligh berupa ceramah tentang agama Islam, berupaya untuk menyampaikan ajaran Islam kepada umat manusia, sekaligus memberikan pengertian, pemahaman dan motivasi, sehingga manusia memahami, menghayati, mengamalkan, serta diharapkan dapat menyampaikan ajaran Islam yang telah diterima kepada orang lain, minimal kepada keluarga terdekatnya.

Dalam mendapatakan materi tentang agama islam, khususnya para penyandang tunarungu wicara mengalami hambatan dalam berkomunikasi, pemilihan bahasa dan mendapatkan informasi. Ketunarunguan jelas mengakibatkan hambatan dalam perkembangan bahasa, karena perkembangan bahasa banyak memerlukan kemampuan pendengaran (Departemen Pendidikan dan Kebudayaan : 1997).

Dalam komunikasi, keterbatasan bahasa ini akan menghambat proses penyampaian pesan-pesan dan informasi ke islaman, serta mengakibatkan penyandang tunarungu wicara mengalami hambatan dalam perkembangan kecerdasan beragama, emosional, kepribadian, kehidupan sosial beragama dan lainya yang membutuhkan bahasa. Keterbatasan ini membuat penyandang tunarungu wicara mengalami kesulitan dalam memahami informasi ke islaman yang mereka dapatkan.

Bahasa isyarat kini menajdi pengganti bahasa lisan saat berkomunikasi para penyandang tunarungu wicara, namun tidak semudah dengan bahasa lisan yang pada umumnya. Karena bahasa isyarat memiliki keterbatasan bahasa yang signifikan. Sehingga sering terjadi kesalah pemahaman, mereka tahu kata namun tidak mengetahui maknanya.

Dalam berkomunikasi atau kepemilihan bahasa, para penyandang tunarungu ini memiliki sistem kebahasaan tersendiri dan memiliki aturan-aturan berbahasa yang berbeda dengan orang normal pada umumnya yang menggunakan bahasa lisan. Dalam mengungkapkan sesuatu, dalam bercerita atau bercanda, meraka akan mempunyai cara sendiri dalam mengungkapkanya. Sama halnya dalam kegiatan tabligh, mereka sebagai umat atau penerima metari tabligh akan mengalami hambatan dalam memahami materi tabligh, begitun dalam pengamalanya, karena dalam menerjemahkan apa yang di sampaikan akan mengalami proses yang berbeda.

Berangkat dari contoh di atas, penyandang tunarungu wicara di Jama'ah Tabligh Al-latifah yang berlokasi di Buah Batu, menjadi objek penelitian yang 
menarik untuk diteliti dengan beberapa alasan; pertama, jamaah tabligh ALlatifah ini memiliki anggota jama'ah dalam berkomunikasi menggunakan bahasa isyarat begitupun dalam kegiatan tablighnya. Kedua, Penyandang tunarungu wicara di Jama'ah Tabligh Al-latifah Buah Batu yang memiliki kegiatan komunikasi dalam bidang dakwah islamiah dalam hal ini tabligh, sehingga relevan dengan keilmuan Komunikasi dan Penyiaran Islam. Ketiga, masih minimnya literatur mengenai Komuniksi Dakwah penyandang tunarungu wicara sehingga dipandang perlu untuk menelitinya. Dalam penelitian ini penulis memaparkan dua penelitian terdahulu yang relevan dengan permasalahan yang akan di teliti mengenai kegiatan tabligh dikalangan penyandang disabilitas rungu wicara.

Abdu Rahman mahasiswa Prodi Komunikasi dan Penyiaran Islam Fakultas Dakwah Dan Komunikasi 2017, dalam skripsinya yang berjudul "Dakwah dikalangan Penyandang Disabilitas Rungu Wicara" (Studi Kasus Tentang Dakwah Ustad Sobirin Rahmat di Balai Rehabilitas Sosial Penyandang Disabilitas (BRSPD) Cibabat Cimahi. Tujuan penelitian Abdu Rahman ini adalah untuk mengetahui kegiatan dakwah dikalangan penyandang disabilitas rungu wicara di Balai Rehabilitas Soial Penyandang Disabilitas (BRSPD) Cibabat Cimahi.

Menurut hasil penelitiannya menunjukkan bahwa dakwah di kalangan penyandang disabilitas tubuh khususnya para penyandang disabilitas rungu wicara memiliki penekana dalam (1) pesan dakwah, (2) media dakwah dan (3) metode dakwah dan hambatan-hambatan dakwah atau gangguan dakwah, hal tersebut meliputi: (1) Gangguan Semantik, (2) Gangguan Fisik (Eksternal), (3) Gangguan Psikologis dan (4) Gangguan Fisiologis. Dari hambatan atau gangguan dakwah tersebut peneliti juga menemukan hambatan pesan, hambatan tersebut meliputi: (a) Hambatan Bahasa, (b) Hambatan Ternis dan (c) Hambatan Bola Salju. Untuk mengatasi hambatan-hambatan dakwah dikalangan penyandang disabilitas tubuh khususnya rungu wicara yaitu dengan cara memperdalam bahasa tubuh dan bahas isyarat, meningkatan kualitas diri, pendekatan secara psikologis dan pengoptimalan diri.

Kinoh mahasiswa Priodi Komunikasi dan Penyiaran Islam Fakultas Dakwah 1998, dalam skripsinya yang berjudul "Evektivitas Komunikasi Total Sebagai Dakwah Di Kalangan Penderita Rungu Wicara ,Penelitiannya bertujuan untuk memenuhi efektifitas komunikasi total sebagai dakwah dikalangan penderita rungu wicara di SLB bagian B Cicendo Bandung. Penelitian ini bertitik tolak dari pemikiran bahwa, proses pelaksanaan dakwah Islam, menurut para guru dan para da'I (komunikator) untuk menggunakan (cara) penyampaian dakwah Islamiyah sesuai dengan kemampuan dan medan pengalaman khalayak, baik dalam bentuk penyampaian dan isi di samping pandai memanfaatkan situasi 
serta kondisi sebagai sarana dakwah yang merupakan sumber utama dalam proses tersebarnya ajaran Islam dan pemahamannya.

Penelitin ini dilaksanakan di Jama'ah Tabligh Al-latifah yang bertempat di Buah Batu sebagai pusat kegiatan dari jamaah penyandang tunarungu wicara, ini juga dikarenakan peneliti menganggap tempat ini representatif dalam pengambilan data baik primer maupun sekuder. Jenis penelitian yang digunakan dalam penelitian ini adalah dekriptif dengan pendekatan kualitatif. Alasan penulis menggunakan metode ini karena peneliti akan langsung mengamati kondisi di lapangan yang berhubungan langsung dengan penyandang tunarungu wicara menyangkut proses tabligh, materi atau pesan tabligh yang disampaiakan dan bagaiamana metode tabligh yang digunakan.

Bogdan dan Taylor mendefinisikan metodologi kualitatif sebagai prosedur penelitian yang menghasilkan data deskriptif berupa kata-kata tertulis atau lisan dari orang-orang dan perilaku yang dapat diamati (J Moleong : 2015). Secara sederhana dapat dinyatakan bahwa penelitian kualitatif adalah meneliti informan sebagai subjek penelitian dalam lingkungan hidup kesehariannya. Dalam metode ini, peneliti memberikan gambaran dan pemahaman mengenai bagaimana proses pelaksanaan kegiatan tabligh, apa saja materi tabligh yang disampaikan dan dengan metode apa yang dilakukan dalam penyampaian materi tabligh pada penyandang tunarungu wicara secara lebih luas dan mendalam.

\section{LANDASAN TEORITIS}

Teori yang di pakai dalam penelitian ini adalah; teori tabligh, dan juga teori komunikasi total. Semua teori ini dikombinasikan menjadi kontruksi kerangka pemikiran dari penelitian ini, yang bertujuan untuk melihat dan memahami proses dakwah islam dalam hal ini tabligh kepada penyandang tunarungu wicara dengan menggunakan bahasa yang memiliki ke khasan yang komplek, yaitu menggunakan bahasa isyarat. Secara bahasa, Tabligh berasal dari kata balagha, yuballighu, tablighan, yang berarti menyampaikan. Tabligh adalah kata kerja transitif, yang berarti membuat seseorang sampai, menyampaikan, atau melaporkan, dalam arti menyampaikan sesuatu kepada orang lain. Dalam bahasa Arab, orang yang menyampaikan disebut Muballigh (Shaleh : 1993).

Tabligh secara umumnya adalah menyampaikan perintah dan larangan Allah SWT. Sebagai ajaran agama agar manusia beriman kepada-Nya. Tabligh lebih dikenali sebagai sifat pengenalan mengenai dasar-dasar mengenai islam. Pelaku yang melakukan tabligh disebut mubaligh. Tabligh adalah bagian dari sistem dakwah islam yang melakukan usaha menyampaikan dan menyiarkan pesan islam yang dilakukan baik secara individu maupun kelompok secara lisan maupun tulisan. Menurut pandangan M. Natsir tabligh berarti ballagh, yang artinya menyampaikan dengan sempurna, seperti dalam kalimat balagul mubin 
yang artinya menyampaikan keterangan yang jelas, sedemikian rupa, sehingga dapat diterima oleh akal dan dapat di tangkap oleh hati, kemudian dapat pula dicerna oleh kedua-duanya (Aziz : 2012). Bahasa dan Komunikasi merupakan produk dari interaski suatu kelompok masyarakat, sehingga setiap kelompok akan memiliki pola komunikasi yang berbeda dari kelompok lain. Begitu juga pada bahasa isyarat, perbedaaan saluran komunikasi (bahasa isyarat dengan sendirinya akan mengakibatkan perbedaan dalam perilaku komunikasi. Hal ini di karenakan tiap budaya akan memiliki praktek komunikasi yang berbeda, di karenakan 'pesan' atau simbol-simbol yang di gunakan berbeda (Djursa : 1994)

Penyandang tunarungu tidak bisa berkomunikasi dengan megandalkan bahasa lisan atau oral saja, karena bahasa lisan penyandang tunarungu tidak dapat berkembang secara wajar. Mereka miskin dalam lambing bahasa, terutama lambing bahasa lisan. Sebagai akibatnya, mereka menggunakan cara lain sebagai pengganti bahasa lisan yaitu dengan isyarat. Isyarat-isyarat yang mereka gunakan sangat beraneka ragam sehingga sulit dipahami oleh lawan bicara. Masyarakat mendengar mengalami kesulitan dalam memahami isyarat yang mereka gunakan, sehingga penyandang tunarungu mengalami hambatan dalam penyesuaian diri dengan masyarakat. Mereka terisolir, sehingga keadaan tersebut dapat menimbulkan gangguan psikologis dalam bentuk wujud rasa rendah diri, merasa terasing, sikap-sikap frustasi dan sebagainya.

Ketunarunguan memberi pengaruh paling besar terhadap bidang perkembangan kemampuan komunikasi dan bahasa seseorang. Bahasa pada dasaranya merupakan cakupan setiap komunikasi dengan menyimbolkan pikiran dan perasaan untuk menyampaikan makna kepada orang lain, salah satunya dibedakan oleh bentuk komunikasi yang luas seperti: tulisan, bicara, bahasa symbol, isyarat, ekspresi muka, gerak tubuh dan lain sebagainya. Denton (1968) menggambarkan komtal sebagai berikut :

The full spectrum of language modes, child devised gesture, the language of signs, speech reading, finger spelling, reading and writing...the development of residul hearing for the enchancement of speech and speech reading skiils. (Bunawan : 1997)

Dari pernyataan diatas dapat diartikan bahwa komunikasi total adalah keseluruahan spectrum cara berbahasa yang lengkap, gesti anak, bahasa isyarat, bahasa ujaran, ejaan jari, membaca dan menulis, pengembangan sisa pendengaran guna memajukan keterampilan biacara dan baca ujaran.Venon (1972 dalam Bunawan (1997: 38) mengemukakan bahwa :

As a constructive soping with the realityof limitation of lipreading...the deaf child is taught dan is given the opportunity to communicate through a system no more ambisious to him than spoken word to bearing child

Dari pernyataan di atas dapat diartikan bahwa komunikasi total merupakan 
cara yang kontruktid dalam menghadapi keterbatasan kemampuan baca ujaran, anak tuli dididik dan diberi kesempatan untuk berkomunikasi dengan suatu system yang tidak meragukan (ambigu) bagi mereka sebagaimana bahasa lisan untuk anak dengar. Sedangkan, memberikan batasan yang dikemukakan dalam suatu Seminar Internasional di London (1975) yang menekankan pada berbagai media komunikasi yang digunakan, yaitu :

Total Communication the use of any and all modes of communication. This includes the use od a sign language system, finger spelling, speech, speech reading, amplification, gestures, pantomime, drawing and writing...exprenssive modes communication and amplification. The individual..may receive through only one of the modes or by two or more modes simultanesously.

Dari pernyataan di atas dapat diartikan bahwa komunikasi total meliputi penggunaan salah satu dan semua modus atau cara komunikasi yaitu penggunaan system bahasa isyarat, ejaan jari, bicara, baca ujaran, amplifikasi (pengerasan), gesti, pantomimic, menggambar dan menulis. Dalam pengungkapan diri dapat misalnya bicara, salah satu bentuk komunikasi manual, dan amplifikasi secara serempak. Untuk penangkapan pesan dapat diterima melalui hanya salah satu atau dua/lebih cara serempak.

Dalam masyarakat, terdapat anggapan bahwa apabila seseorang tidak bereaksi terhadap suara, maka orang tersebut pastilah tuli. Anggapan ini, tidaklah selalu benar, karena pengertian tuli itu sendiri masih sangat kabur, dan tidak menggambarkan keadaan yang sebenarnya. Berikut adalah batasan yang umum digunakan dikalangan pendidikan luar biasa mengenai definisi tunarungu : Secara medis tunarungu berarti : kekurangan atau kehilangan kemampuan mendengar yang disebabkan oleh kerusakan atau tidak berfungsinya sebagian atau seluruh alat-alat pendengaran. Secara pedadigis tunarungu berarti: kekurangan atau kehilangan pedengaran yang mengakibatkan hambatan dalam perkembangan basaha sehingga memerlukan pendidikan khusus. (Salim : 1984)

Kehilangan kemampuan mendengar disebabkan oleh rusaknya atau tidak berfunsinya sebagian atau seluruh alat pendengaran. Proses pendengaran terjadi melalui getaran udara yang di hasilkan oleh bunyi, benda atau suara yang kemudian diterima oleh alat-alat pendengaran. Pada batas lubang telinga, getaran ini diterima oleh membrane tympani, yang membatasi telinga bagian luar dengan telinga bagian tengah saling berhubungan, yaitu malleus, incus, dan stapes. Ujung tulang sanggurdi (stapes) yang melekat pada fanestra vestibule ovalis akan meneruskan getaran tadi ke telingan bagian dalam (cochlea).

Cochlea merupakan bagian yang terpenting dalam telinga dan berisi cairan. Getaran yang diterima dari fanestra vestibule ovalis akan diubah menjadi rangsangan pendengaran oleh coclea ini. Rangsangan pendengaran kemudia diserap oleh alat corti yang merupakan ujung dari syaraf pendengaran. Syaraf inilah yang 
meneruskan rangsangan ke pusat kesadaran (wernickle). Pada wernickleI diolah dan disimpan berbagai macam pengertian atau konsep, sehingga sadarlah manusia akan adanya suatu bunyi.

Jika satu atau beberapa alat pendengaran tersebut di atas rusak segingga tidak berfungsi sebagai mestinya, maka getaran udara tidak dapat diteruskan dan diubah menjadi kesan suara dab tanggapan pendengaran. Keadaan inilah yang dinamakan gengan tunarungu. Kondisi tunarungu biasanya disertai dengan tunawicara (tidak bisa berbicara) karena telinga memang berhubungan langsung dengan mulut. Hubungan ini terjadi dengan adanya salutran eustachius, yang menghubunglkan rongga telinga bagian tengah dengan rongga mulut.

Saluran ini pada hakikatnya berfungsi untuk memelihara keseimbangan tekanan udara yang melalui membrane tympani. Keseimbangan tekanan udara luar dengan telinga bagian tengah, penting untuk bisa diteruskannya getaran. Karena tidak semua getaran diteruskan maka kerja saluran ieutachius menjadi terganggu, dan terjadilah kondisi yang dinamankan tunawicara. Sehingga bisa disimpulkan, yang dimaksud dengan tunarungu adalah seseorang yang mengalami kekurangan atau kehilangan kemampuan mendengar yang disebabkan oleh kerusakan atau tidak berfungsinya sebagian atau seluruh alat pendengaran, sehingga ia mengalami hambatan dalam bahasa bahkan tidak bisa berbicara.

\section{HASIL DAN PEMBAHASAN}

Dalam sepuluh tahun terakhir, ada salah satu gerakan muslim di Bandung pertumbuhannya yang cepat baik dalam jumlah anggota maupun dengan jangkauan wilayah. Gerakan ini memiliki ciri yang berbeda di mana sebelumnya Indonesia memiliki gerakan gerakan Islam yang sudah ada sejak dahulu di antaranya NU, Muhammadiyah dan Persis. Gerakan muslim ini menyentuh semua umur dan kalangan dari mulai anak-anak hingga orang tua, dari mulai pedagang, pengusaha, preman bahkan para artis juga banyak yang masuk gerakan ini.

Tercatat dalam kargozali (perkumpulan) yang dilakukan di masjid Agung Bandung ada ada 5000 orang yang menghadiri perkumpulan tersebut. Bahkan jumlah tersebut semakin banyak bila terjadi perkumpulan di tingkat Provinsi Jawa Barat. Hal Ini membuktikan bahwa gerakan ini begitu cepat pertumbuhannya serta diterima banyak kalangan oleh seluruh lapisan masyarakat Indonesia. Gerakan muslim ini menamakan gerakannya dengan sebutan nama Jamaah Tabligh (A. B. A. Abduh : 2008). Atas pencapaiann Jamaah Tabligh yang terbilang luar biasa itu tidak lepas kepada para perintis yang memulai menyebarkan pemahaman ini. Sehingga gerakan ini masuk ke Indonesia kemudian masuk Bandung. Hampir seluruh anggota jama'ah tahu siapa Maula Muhammad Ilyas pendiri gerakan ini. 
Bernama lengkap Maulana Muhammad Ilyas bin Muhammad Ismail alHanafi ad-Diyubandi al-Jisti al-Kandahlawi (1885-1944) di Mewat, Delhi selatan, India. Ia memiliki hubungan yang sangat kuat dengan tarekat naqshabandiah yang lebih menekankan kepada ke Shufian dalam beribadah. Ia lahir pada tahun 1885 di sebuah kota yang bernama Kadhla, wilayah Muzaffarnar, dan berasal dari keluarga yang taat serta memiliki komitmen reformasi keberagaman, seperti telah dikobarkan oleh tokoh India abad ke 19, Shah Waliullah (1703-62) (E. Amin : 2012).

Setelah berkembang pemahaman Jamaah Tabligh di India hingga mencapai kesuksesan saat dipimpin oleh Maulana Ilyas di mana ia berhasil mengadakan pertemuan di Mewat yang dihadiri oleh 25000 orang. Bahkan Syaikh Abul A'la Al-Maududi mengatakan bahwa gerakan ini adalah langkah besar untuk proses Islamisasi komunitas Muslim di India. Setelah meninggalnya Maulana Ilyas, kepemimpinan Jamaah Tabligh diambil alih oleh putranya Maulana Muhammad Yusuf (1917-1965).

Pada periode Muhammad Yusuf perkembangan Jamaah Tabligh semakin diperluas. Misi utamanya adalah menyebarkan pemahaman Jamaah Tabligh ke seluruh dunia. Ia berhasil menyebarkan ke seluruh India, Pakistan, Bangladesh, Timur Tengah, Afrika, Eropa, Amerika dan Asia Tenggara. Ada tiga negara yang dilewati kelompok Jamaah Tabligh ketika mengunjungi Asia Tenggara yaitu Malaysia, Singapura dan Indonesia. ketiga negara ini menjadi tujuan utama mereka karena mayoritas umat Islam berada di sana.

Untuk memetakan kapan masuknya Jamaah Tabligh ke Indonesia ada beberapa pendapat yang sama yang menyebutkan mengenai kapan pertama kali gerakan ini masuk dan berkembang di Indonesia. Pendapat pertama mengatakan bahwa para pembawa pertama yaitu orang orang India yang berjumlah 8 orang yang tidak disebutkan namanya. Mereka tiba di Jakarta Pebruari 1955 dan tempat pertama yang mereka singgah adalah Haji Zaristan Khan, orang Indonesia keturunan India. (A. Aziz : 2004).

Pendapat lain juga yang ditulis oleh Abdul Aziz menyebutkan hal yang sama. Gerakan Jamaah Tabligh dibawa oleh Miaji Isa. Mereka tiba di Medan sekitar tahun 1952 dan mereka dipanggil sebagai Jamaah Khuruj, yaitu kelompok yang selalu berjalan jalan di jalan Allah yang bertugas berdakwah dan mengajak taat kepada Allah SWT. Hanya gerakan ini mulai intensif berdakwah sekitar tahun 1974 di Masjid Kebon Jeruk, Jakarta.(E. Amin : 2012)

Oleh karena itu, masuknya Jamaah Tabligh ke Indonesia pertama kali dibawa oleh Miaji Isa sebagai pemimpin rombongan pada tahun 1952. Ia mendapat tugas sebagai delegasi penyebaran di Asia Tenggara. Sebelum masuk ke Indonesia, ia sempat juga masuk ke Malaysia. Kota pertama yang menjadi awal masuknya Jamaah Tabligh ada Medan di mana ada satu wilayah yang 
kebanyakan adalah muslim India. Mereka disambut hangat kemudian menjadikan Masjid Al-Hidayah menjadi markas pertama mereka sebagai titik awal dakwah di Indonesia. Setelah Jamaah Tabligh masuk ke Indonesia, kelompok ini mulai menyebarkan pemahamannya ke seluruh nusantara. Target utama mereka adalah wilayah yang mayoritas berpenduduk Islam terbanyak di antara semua wilayah yang ada di Indonesia. Salah satu wilayah yang menjadi perhatian dan terbanyak mayoritas Islam terbesar adalah Jawa Barat. Dengan mayoritas hampir semuanya memeluk agama Islam maka tidak heran Jawa Barat menjadi tujuan utama dan salah satu kotanya adalah Bandung.

Jika kita tarik kapan dan oleh siapa gerakan Jamaah Tablig di Bandung masuk, hanya sedikit sumber yang membahas mengenai sejak kapan mulai masuknya gerakan itu. Disamping itu, dari tiap sumber memiliki data yang berbeda terkait kapan masuknya Jamaah Tabligh ke Bandung. Pendapat lain menyebutkan bahwa masuknya Jamaah Tabligh ke Bandung adalah pada tahun 1980. Sumber ini menyebutkan orang Bandung pertama yang menerima pemahaman Jamaah Tabligh adalah Muzzakir pada tahun 1980. Menurut Ajid Hakim, ia adalah orang Aceh yang merantau ke Bandung dan kini enjadi seorang penerbit Pustaka. (A. Hakim : 2013)

Sumber lain juga menyebutkan bahwa orang Bandung pertama yang masuk Jamaah Tabligh yaitu Ustd A Muzzakir. Pada saat itu, ia adalah salah satu pensiunan polisi (PORLI) yang tinggal di Bandung. Pada tahun yang sama, ia berupaya mendirikan markas untuk Jamaah Tabligh di Bandung dan sekitar tahun 1987 Jamaah Tabligh di Bandung mulai terlihat perkembangan yang positif di mana pada saat itu Jamaah Tabligh yang dipimpin oleh Ustd A Muzzakir memimpin Jamaah Tabligh berdakwah di Bandung selama lima belas hari.

Untuk melihat bagaimana Jamaah Tabligh tumbuh di Bandung, kita bisa melihat bagaimana mereka menempati masjid masjid yang ada di Bandung. Pada periode 1986 sampai 1996, Jamaah Tabligh terus berpindah pindah masjid mulai dari Masjid Al Furqon Kebon Pisang Kosambi tahun 80-an. Kemudian pindah ke Masjid al-Muhajirin Buah Batu, setelah itu kemudian ke Masjid Agung Bandung, Pindah lagi ke Baitul Muttaqin Antapani/Masjid Pancasila, lalu pindah ke al Madianah dan pada tahun 2017 pindah ke Masjid Al-Latifah Buah Batu sampai sekarang. Proses ini memungkinkan tersebarnya Jamaah Tabligh ke berbagai penjuru Bandung. (A. Hakim : 1986-2013)

Gerakan Jamaah Tabligh semakin hari semakin cepat pertumbuhannya. Bahkan setelah tahun 2000, gerakan ini hampir dikenal oleh seluruh masyarakat Indonesia dan menjadi gerakan yang paling besar basis masanya. Pertumbuhan ini bisa dilihat dari jumlah anggota Jamaah Tabligh yang menempati masjid sebelumnya. Jamaah Tabligh sebelumnya menempati masjid Baitul Muttaqin 
yang sebelumnya hanya berjumlah 90-120-an orang. Dalam sumber ini tidak disebutkan secara jelas berapa jumlah yang hadir, namun pewawancara menyebutkan pada tahun 1994 sekitar 3 saf yang diisi oleh anggota Jamaah Tabligh yang bila dijumlahkan sekitar 20-30 orang per saf. Pertumbuhan Jamaah Tabligh di masjid itu kiat tak terkendali dari yang mula 3 saf dari 50 saf menjadi membludak keluar.

Bahkan tercatat ada sekitar 2000 orang yang menghadiri perkumpulan pada malam Jumat. Hingga akhirnya pada tahun 2003 markas Jamaah Tabligh pindah ke masjid al-Madinah Antapani di jalan, lalu demi untuk memperluas penyebaran, pada tahun 2017 markas berpindah ke Masjid Al-Latifah Buah Batu.

\section{Proses Tabligh terhadap Penyandang Tunarungu Wicara di Jama'ah Tabligh Al-latifah Buah Batu}

Dilihat dari kondisi fisik memang tidak ada perbedaan antara penyandang tunarungu wicara dengan mereka manusia pada umumnya, hanya saja mereka punya kekurangan dalam pendengaran dan lisan. Dilihat dari kondisi kejiwaan juga hampir sama dengan manusia pada umumnya, hanya terdapat perbedaan yang mengakibatkan mereka memiliki cara tersendiri dalam berkomunikasi, hal ini juga mengakibatkan perbuhan dalam semua aspek kehidupan sehari-hari. Mereka memiliki hak yang sama dengan manusia normal lainya, tak terkecuali dalam hak mendapatkan wawasan ke Islam seperti umat manusia yang lainnya, namun mereka memiliki hambatan dalam mendapatkan informasi, dikarenakan keterbatasan dalam berkomunikasi.

Kegiatan tabligh yang di lakukan terhadap Penyandang Tunarungu ini sudah di lakukan di Pakistan pada 30 tahun ke belakang, lalu menyebar ke Bangladesh, India dan Malysia, pada akhirnya atas ajakan Jama'ah Malaysia yang bergerak ke Indonesia, kegiatan tabligh ini baru sampai pada 7 tahun yang lalu di Jakarta. Yang pertama menyambut Usaha Dakwah ini adalah Ust. Farid dan Ust. Aziz yang sekarang menjadi penanggung jawab Dakwah kepada Penyandang Tunarungu di Indonesia. Untuk di Bandung sendiri yang pertama kali memulai Usaha ini adalah Ust. Abu Kahfi yang sekarang menjadi Koordinator Dakwah ke Penyandang Tunarungu Wicara di Bandung sampai sekarang. Pada akhirnya ada beberapa Ustad yang dibina untuk menjadi mubaligh untuk penyandang tunarungu.

Awal pembinaan terhadap para ustadz ini dilakukan oleh para Jama'ah tunarungu wicara sendiri yang datang dari Malaysia, para juru dakwah ini di ajak untuk mengunjungi organisasi tuna rungu wicara, SLB di sekitar Bandung, mereka di ajarkan berkomunikasi dengan menggunakan Bahasa Isyarat di mulai alfabet, kosa kata dan sebagainya, sekaligus juga melibatkan para penyandang tunariungu wicara yang ada di tempat. 
Dalam kunjungan ini juga Jama'ah Tabligh ini mengsosialisasikan adanya usaha dakwah kepada Penyandang Tunarungu Wicara yang bertujuan untuk mengenalkan agama kepada panyandang tuna rungu wicara. Setelah para juru dakwah ini memiliki dasar kemampuan dalam menggunakan Bahasa Isyarat, maka dimulialah usaha dakwah yang bertujuan menyampaikan usaha ajaran islam kepada penyandang tuna rungu wicara. Pada awal ajakanya dengan cara pintu ke pintu atau kunjungan kepada keluarga yang memiliki penyandang tunarungu wicara melalui data yang di dapatkan dari Organisasi Penyandang Tunarungu Wicara ataupun SLB di sekitar Bandung.

Kegiatan tabligh terhadap penyandang tunarungu wicara ini pelaksaaannya tidak dilakukan di masjid Al-Alatifah Bauh Batu saja, karena dalam pengumpulan jamaah tunarungu wicara ini di tempatkan pada 3 lokasi, yaitu di Masjid AlMa'soem Cikalang terdapat 4 orang penyandang tunarungu, masjid Surapatikor terdapat 16 orang, dan di masjid An-nabawi Cimahi 20 orang. Semua jumlah penyandang tunarungu wicara ini yang terbilang aktif hanya 60 orang, namun terhitung untuk yang pernah mengikuti kajian 100 orang. Berkurangnya jama'ah tunarungu wicara ini di akibatkan tidak semua keluarga penyandang tunarungu wicara ini mengizinkan keluarganya untuk mengikuti kajian. Pada tiga tempat ini di tanggung jawabkan pada masing masing Ustadz yang tugasnya menyampaikan materi kajian dan juga menerjemahkan materi yang disampaikan oleh penceramah lainya. Untuk penanggung jawab di masing-masing tempat adalah Ustad yang berdomisili di daerah masjid tempat kumpul, Ustad H Enan di Masjid Al-Ma'soem Cikalang, Ustad Yahya dan Ustad Ihsan di Masjid AnNabawi Cimahi, Ust Kahfi di masjid Surapatikor. Pada pelaksanaannya tidak bisa di pungkiri akan menemukan berbagai macam hambatan, baik hambatan dari para Penyandang disabilitas tunarungu wicara maupun hambatan dari para ustadz. Hambatan-hambatan tersebut adalah :

Perbedaan Kemampuan dalam Berbahasa IsyaratHampir setengah dari mereka masih sulit menggunakan dan memahami bahasa isyarat, sebab latar belakang mereka berbeda-beda ada yang dari kecil sudah berada di bangku sekolah dan ada juga yang tidak menjalani pendidikan sekolah, hal tersebut membuat mereka yang belum memahami bahasa isyarat menjadi terhambat dan daya tangkap serta pemahaman sedikit lama dari pada dengan jama'ah yang sudah memahami bahasa Isyarat. Hal tersebut juga menjadi sebuah hambatan yang dimiliki pada para penyandang disabilitas rungu wicara dikarenakan mereka menjadi lebih lambat memahami materi yang sudah disampaikan. Baik juga dari para ustad yang terkadang menemukan kosa kata yang baru, sehingga dalam penyampaiannya memerlukan proses yang cukup lama sehingga para jama'ah tunarungu wicara memahaminya.

Hamabatan dari luar Sering terjadi pengurangan jama'ah yang hadir, hal ini 
di sebabkan dari pihak keluarga para jama'ah ini tidak memberikan izin untuk mengikuti kegiatan tabligh ini. Dan juga pihak keluarga ada yang menganggap bahwa kegiatan keagamaan ini sudah cukup di dapatkan di bangku sekolah. Ada juga yang keluarga jama'ah tunarungu wicara ini tidak memperhatikan kehidupan beragama para penyandang tunarungu ini sehingga, mereka memilih untuk lebih mementingkan hal lain seperti keterampilan, kesejahteraan dan sebagainya. Hal ini mengakibatkan tidak kesamaanya pemahaman para jama'ah tunarungu wicara yang rutin dan jama'ah yang tidak rutin dalam hadir mengikuti kajian. Oleh karena itu ada upaya dalam mengatasi hambatan-hambatan, guna mengoptimalkan peyampaian materi menjadi lebih baik lagi :

Memperdalam Bahasa Isyarat Komunikasi Total. Karena bahasa tubuh atau bahasa isyarat dapat menjadi komunikasi yang efektif jika komunikan dan komunikator sama-sama saling memahami makna dari bahasa isyarat dan tubuh yang mereka sampaikan. Jika seorang mubaligh dan mubalagh sudah sama-sama saling memahami bahasa isyarat dan bahasa tubuh maka sudah dapat dipastikan tabligh dikalangan penyandang disabilitas sama-sama saling difahami dan kemungkinan besar materi tabligh yang disampaikan dengan efektif kepada para penyandang disabilitas khususnya penyandang disabilitas rungu wicara.

Pendekatan Secara Psikologis, untuk mengatasi hambatan-hambatan saat melakukan ceramah di kalangan penyandang disabilitas para dai harus mendekatkan diri kepada para jama'ah penyandang disabilita rungu wicara dan harus memiliki keinginan yang tinggi untuk memberikan motivasi dan ilmu kepada para penyandang lewat ceramah yang kita sampaikan kepada para jama'ah penyandang disabilitas rungu wicara.Selain itu kita harus selalu memberikan motivasi kepada pihak keluarga penyandang tunarungu wicara ini agar mengetahui pentingnya wawasan agama yang memang hak mereka untuk mendapatkannya. Dan juga meningkatakn motivasi kita maupun para penyandang disabilitas khususnya rungu wicara supaya kita sama-sama lebih bersemangat untuk menjalankan hidup kearah yang di muliakan oleh Allah Swt, dan menjadikan sebuah hambatan menjadi motivasi kita melangkah menyebarkan agama Allah baik kepada masyarakat umumnya, maupun kepada penyandang disabilitas tunaungu wicara.(Ustad H Enan, Wawancara, Selasa, 27 November, 2018 di Bandung).

\section{Materi tabligh yang disampakan terhadap penyandang tunarungu wicara di Jama'ah Tabligh Al-latifah Buah Batu}

Materi tabligh adalah salah satu unsur penting dalam kegiatan tabligh, bahkan dalam situasi tertentu, keberhasilan kegiatan tabligg ini sangat bergantung dari materi yang disampaikan. Dalam penyampaikan materi kepada penyandang tunarungu wicara ini, para mubaligh biasanya membahas yang berkaitan dangan 
materi motivasi untuk meningkatkan motivasi hidup serta menggunakan teknik praktek-praktek keagamaan yang meliputi peraktek sholat, mengaji, ketauhidan, akhlak yang mengarah kearah ibadah yang praktis tetapi tidak keluar dari sariat Islam. Semua materi yang disampaikan bersumber kepada al-Qurean dan Hadist. Tanpa memandang berbagai golongan Islam (NU, Persis, Muhammadiyah, dll) yang ada di Indonesia, yang umum saja yaitu madzhab Imam syafie $i$. Berdasarkan hasil observasi yang dilihat dari pelaksanaan tabligh terhadap penyandang Tunarungu wicara ini materinya adalah sebagai berikut:

Masalah akidah merupakan masalah pokok yang menjadi materi kegiatan dakwah, karena aspek iman dan akidah merupakan komponen utama yang akan membentuk moralitas atau akhlak. Materi ini merupakan materi inti dari yang di sampaikan kepada jamaah tanarungu wicara, dikarenakan masalah akidah merupakan masalah utama kita selaku umat. Dari ceramah yang di sampaikan permasalahan akidah yaitu tentang memberikan pemahaman atau sebuah kajian tentang Rukun Iman dan Rukun Islam kepada para penyandang disabilitas yang berada di Jama'ah Tabligh Al-Latifah Buah Batu Kota Bandung.Pembahasan mengenai akidah tidak sekedar tertuju pada masalah- masalah yang wajib di imani, akan tetapi materi tabligh meliputi juga masalah-masalah yang dilarang sebagai lawanya misalnya syirik, mengingkari Allah Swt dan sebagainya.

Penyampaian materi tabligh mengenai tauhid Islam (Akidah) sangat penting untuk dilakukan, terutama bagi pemula. Pertentangan mengenai Akidah ditengah umat Islam relatif lebih minim dibanding pertentangan terkait masalah Fiqih. Maka akan sangat berbahaya bagi mubaligh pemula untuk menyampaikan materi Fikih jika ilmu yang dimiliki belum terlalu banyak.

Syariat dalam Islam adalah berhubungan erat dengan amal lahir (dhohir) dalam rangka mentaati semua peraturan atau hukum Allah guna mengatur hubungan antara manusia dengan tuhannya dan mengatur pergaulan hidup sesama manusia. Berarti bahwa Syariat menyangkut masalah amaliyah dari setiap muslim yang ditentukan oleh adanya perintah dan larangan Allah SW'T yang menyangkut semua aspek, baik bidang khusus yaitu hubungan dengan Allah Swt, maupun ibadah umum yaitu hubungan dengan sesama manusia.

Pada permasalahan yang berkaitan dengan masalah syariaat materi yang disampaikan kepada para penyandang disabilitas bahwa setiap manusia harus berguna untuk manusia yang lainnya. Dengan motivasi tersebut bertujuan untuk untuk membentuk karakter para penyandang disabilitas supaya patuh kepada syariaat agama Islam Masalah muamalah lebih memperhatikan aspek kehidupan sosial dibanding kehidupan ritual dalam melaksanakan nilai-nilai keagamaan. Beliau lebih menekankan ciri khas supaya kita sesama manusia harus saling menolong seperti yang di anjurkan oleh Agama Islam, dari permasalahan tersebut penyampaian materi ini membangun rasa sosial kepada para penyandang 
disabilitas untuk saling membantu sama lain seperti. Dari itu semua akan terbentuknya jiwa sosial mereka yang tidak terlepas dari nilai-nilai agama Islam.

Masalah akhlak merupakan masalah yang senantiasa bersifat nampak pada tingkah laku manusia dan sudah menjadi darah daging atau sudah menjadi tabi'atnya sejak lahir. Dalam penyampain materi selalu menekankan supaya para penyandang disabilitas, bisa memiliki akhlak yang baik, dan juga menekankan bahwa agar para penyandang disabilitas bisa menyampaikannya kembali kepada teman-temannya walau hanya dengan waktu yang singkat yang dilakukannya dengan bahasa isyarat. Dari hal yang kecil terdahulu materi yang disampaikan untuk membuat para jama'ah penyandang disabilitas rungu wicara untuk menerapkan nilai-nilai yang dianjurkan agama Islam untuk menerapkannya kepada sesama. (Ustad Ihsan, Wawancara, tanggal 22 November 2018)

\section{Metode yang di lakukan dalam penyampaian materi tabligh terhadap penyandang tunarungu wicara di Jama'ah Tabligh Al-Latifah Buah Batu}

Para penyandang tunarungu wicara ini memiliki komunikasi yang berbeda, pertama, penggunaan bahasa oral/membaca ujaran untuk berkomunikasi, dengan cara membaca gerak lisan, kedua adalah bahasa isyarat yang menggunakan ejaan jari dan mimik/ekpresi wajah. Perbedaan ini membutuhkan pendekatan, yaitu pendekatan Komunikasi Total yang merupakan bahasa pengganti saat terjadinya komunikasi yang bersifat tidak bersuara, yang meliputi penggunaan system bahasa isyarat, ejaan jari, bicara, baca ujaran, amplifikasi (pengerasan), gesti, pantomimic, menggambar dan menulis.

Metode Bahasa Komunikasi Total ini untuk menunjang kegiatan tabligh para Ustad kepada penyandang disabilitas tunarungu wicara di Jama'ah Tabligh Al-Latifah Buah Batu Kota Bandung. Pada pelakasanaanya, di disediakan Ustad menerjemahkan bahasa lisan menjadi bahasa isyarat untuk disampaikan kepada orang orang yang tuna runggu wicara. Biasanya mereka berkumpul dibelakang jamaah yang berkumpul tetapi jaraknya saling berdekatan. Untuk yang mengikuti ceramah lewat bahasa isyarat ini cukup banyak sekitar 10-30 orang yang selalu hadir di malam Jum'at. (Ustad Yahya. Wawancara, 22 November 2018)

Metode ini juga perkuat Sistem bahasa Isyarat Indonesia (SIBI) dan Bahasa Isyarat Indonesia (BISINDO). SIBI merupakan bahasa isyarat baku yang di gunakan di linkungan sekolah, dan Sibi pun tidak memiliki landasan hukum yang baik dan bahasa isyarat tersebut merupakan terjemahan bahasa isyarat dari amerika serikat yang secara linguistic yang ebih banyak terdiri dari pengisyaratan abjad, sedangkan Bisindo kamus yang di kembangkan oleh Gerakan Untuk Kesejahteraan Tuna Rungu Indoneisa (GERKATIN) itu lebih mudah untuk digunakan dalam bahasa sehari-hari.

Dalam metode ini juga tidak hanya sebatas penyampaian materi saja, 
namun setelahnya dalam beberapa kegiatan, para ustad mempraktikan dan memberikan pengertian dengan menggunakan bahasa isyarat Komunikasi Total, ada beberapa kegiatan yang dilakukan, seperti:

Pengajian rutin ini dilaksanakan setiap satu minggu sekali, dan di fokuskan pada tiga titik kajian. Untuk yang laki-laki dilaksanakan setiap hari Kamis jam 18.00 (Ba ${ }^{e e}$ da Magrib) sampai 21.00 (Ba ${ }^{e e}$ da Isya) WIB di masjid yang sudah di tentukan. Sedangkan untuk yang wanita dilaksanakan setiap hari Minggu jam 09.00 sampai 12.00 (Ba ${ }^{\text {ee }} \mathrm{da}$ Dzuhur) WIB di rumah para istri pembinging jama'ah yang juga penerjemah bahasa isyarat.

Pengajian Intensif, pengajian ini berkonsep Majlis Taklim. Ustad dan Ustadzahnya menyampaikan materi dengan menggunakan Bahasa Isyarat. Pengajian pun kadang tak sesuai jadwal, terkadang ada laki-laki yang datang hari Minggu dan wanita pada hari Kamis. Jika dalam pengajian itu ada laki-laki dan wanita, maka pengajian laki-laki dan wanita dipisah tempatnya.

Pengajian Intensif Masturoh, pengajian ini dilakukan sebagai program lebih membiasakan semua perbuatan Nabi Muhammad SAW dalam semua aspek kehidupan. Dilaksanakan setiap tiga bulan sekali. Mereka diajarkan semua kebiasaan Rasulullah Saw. Pengajian ini lebih mempraktikan apa yang sudah disampaikan pada kajian sebelumnya, mulai bangun tidur, cara mandi, cara berpakaian, cara makan, dan seterusnya sampai mereka tidur lagi. Untuk yang sudah menikah diajarkan pula cara bergaul dengan pasangannya

Pengajian Bulanan, pengajian ini dilakukan termasuk dalam pengajian rutin. Hanya pengajian bulanan ini dilaksanakan di tempat lain. Contohnya pada tanggal 29 November 2018 dilaksankan di daerah Cilember Cimahi. Biasanya orang-orang normal yang mengundang Tunarungu untuk mengaji bersama mereka. Tetapi tetap saja materi yang didapat dengan menggunakan bahasa Isyarat. Dengan pengajian bulanan ini, menjadi suatu momen syukur terhadap Allah bahwa terdapat orang Tunarungu tetapi mereka masih giat belajar agama ( Ustad Ihsan, Wawancara, tanggal 2 November 2018).

\section{PENUTUP}

Berdasarkan hasil penelitian seluruh uraian diatas yang menyangkut kegaiatan Tabligh terhadap penyandang disabilitas tunarungu wicara dapat disimpulkan bahwa:

Pertama, kegiatan tabligh yang di lakukan oleh jama'ah tabligh Al-Latifah Buah Batu terhadap Penyandang Tunarungu Wicara dilakukan pada 7 tahun yang lalu. Awal pembinaan dilakukan terhadap para mubaligh ini dilakukan oleh para Jama'ah tunarungu wicara sendiri yang datang dari Malaysia, mereka di ajarkan berkomunikasi dengan menggunakan Bahasa Isyarat di mulai alfabet, kosa kata dan sebagainya, sekaligus juga melibatkan para penyandang tunariungu 
wicara yang ada di tempat. Pada pelaksanaannya tidak bisa di pungkiri akan menemukan berbagai macam hambatan, Hambatan-hambatan tersebut adalah : (a) Perbedaan Kemampuan dalam Berbahasa Isyarat, (b) Hambatan lainya. Oleh karena itu ada upaya dalam mengatasi hambatan-hambatan, guna mengoptimalkan peyampaian materi menjadi lebih baik lagi : Mempedalam Bahasa Isyarat Komunikasi Total, (b) Pendekatan Secara Psikologis

Kedua, materi tabligh yang disampaikan terhadap penyandang tunarungu wicara di Jama'ah Tabligh Al-latifah Buah Batu Materi tabligh adalah salah satu unsur penting dalam kegiatan tabligh, bahkan dalam situasi tertentu, keberhasilannya kegiatan tabligh sangat bergantung dari materi yang disampaikan. Dalam penyampaikan materi kepada penyandang tunarungu wicara ini, para mubaligh biasanya membahas yang berkaitan dangan materi motivasi untuk meningkatkan motivasi hidup serta menggunakan teknik praktek-praktek keagamaan yang meliputi peraktek sholat, mengaji, ketauhidan,akhlak, muamalah yang mengarah kearah ibadah yang praktis tetapi tidak keluar dari sariat Islam.

Ketiga, para penyandang tunarungu wicara ini memiliki komunikasi yang berbeda, pertama, penggunaan bahasa oral/membaca ujaran untuk berkomunikasi, dengan cara membaca gerak lisan, kedua adalah bahasa isyarat yang menggunakan ejaan jari dan mimik/ekpresi wajah. Perbedaan ini membutuhkan pendekatan, yaitu pendekatan Komunikasi Total yang merupakan bahasa pengganti saat terjadinya komunikasi yang bersifat tidak bersuara, yang meliputi penggunaan system bahasa isyarat, ejaan jari, bicara, baca ujaran, amplifikasi (pengerasan), gesti, pantomimic, menggambar dan menulis.

Metode Bahasa Komunikasi Total ini untuk menunjang kegiatan tabligh para Ustad kepada penyandang disabilitas tunarungu wicara di Jama'ah Tabligh Al-Latifah Buah Batus. Dalam metode ini juga tidak hanya sebatas penyampaian materi saja, namun setelahnya dalam beberapa kegiatan, para ustad mempraktikan dan memberikan pengertian dengan menggunakan bahasa isyarat Komunikasi Total, ada beberapa kegiatan yang dilakukan, seperti: (a) Pengajian Rutin, (b) Pengajian Intensif, (c) Pengajian Intensif Masturoh (d) Pengajian Bulanan.

\section{DAFTAR PUSTAKA}

Abdul Aziz, (2004) The Jamaah Tabligh Movemen In Indonesia: Peaceful Fundamentalist, Journal Internasional, Studi Islamika, Volume 11, no 3,

Abu Muhammad bin Ahmad Abduh (2008). Kupas Tuntas Jamaah Tabligh, Bandung: Khoirul Ummat

Ajid Hakim, (1986-2013) Gerakan Sosial Jamaah Tabligh Studi Kasus di Bandung. Desertasi. Bandung, Universitas Islam Sunan Gunung Djati Bandung, hlm. 


\section{4-236}

Abdul Rosyad Shaleh (1993), Manajemen Dakwah Islam, Jakarta: Bulan Bintang, cet. $\mathrm{Ke}-3$

AS. Enjang dkk, (2009), Dasar-dasar Ilmu Dakwah Pendekatan Filosofi dan Praktis . Bandung: Widya Padjajaran.

Bunawan, Lani. 1997.Komunikasi Total. Jakarta: Depdikbud hlm.38)

Departemen Pendidikan dan Kebudayaan.1997. Pendidikan Anak-Anak Tunarungu. Jakarta : Departemen Pendidikan dan Kebudayaan.

Edi Amin.(2012),Dakwah Rahmatan li al-Alamin Jamaah Tabligh di Kota Jambi, Jurnal Komunikasi Islam IAIN Sunan Ampel.

Lexy J Moleong,(2015), Metodologi Penelitian Kualitatif Bandung: Remaja Rosda Karya.

Moh. Ali Aziz (2012), Edisi Revisi Ilmu Dakwah. Jakarta: Prenada Media Group.

Sendjaja, S. Djursa (1994), Teori Komunikasi. Jakarta: Universitas Terbuka.

Saepuloh , Ujang,(2009),SS Model Komunikasi Jamaah Tabligh : Academic Journal for Homilete Studies.

Salim, Mufti. 1984. Pendidikan Anak. Tunarungu. Jakarta.: Departemen Pendidikan dan Kebudayaan. Hlm. 7-8 